\title{
SLOVENIAN TOURISM CURRICULA ANALYSIS
}

\author{
Katarina Mušič \\ Janez Mekinc, PhD \\ Helena Cvikl, M.Sc. \\ Timotej Prelog
}

University of Primorska, Faculty of Tourism Studies -

Turistica, Portorož, Slovenia

\begin{abstract}
Advances are required in the Slovenian tourism education system in order to successfully cope with current and future issues and achieve balanced development. This research is focused on Slovenian undergraduate educational programmes in Tourism. We analysed the contents of the programmes, appointed relevant skill sets and later analysed the representation of said skill groups through the programmes' taught skills. We then compared the mean representation of skills and skill sets to those skills considered a requirement by Slovenian tourism. In addition, a comparison with more general theories of balanced tourism education was made. The evidence suggests that Slovenian undergraduate tourism education programmes are relatively well-equipped for serving the staffing needs of Slovenian tourism, however they still lack the fundamental balance between vocational, academic and transferrable skills in order to achieve theoretically ideal forms of tourism education programmes.
\end{abstract}

Keywords: Curriculum, education, tourism, programs, competencies

\section{Introduction}

In this study, we questioned the education dimension of tourism in Slovenia. From curricula content, we reviewed the knowledge and competencies that educational institutions provide tourism operators and tourism industry managers. Within Slovenia, there is an assumption that we have an effective Bologna Process higher education system for Tourism. The aim of this research is the analysis and comparison of study program content in the field of tourism, with particular emphasis on the competencies that these courses provide. In the study, due to missing data, we could not include 
all factors that affect the education system, but we managed to effectively explore Slovenian undergraduate tourism education and its characteristics.

\section{Theoretical assumptions about the ideals of education in tourism}

In this study we encountered two problems: the first is related to the information on study programs in the field of tourism offered by higher education institutions in Slovenia. This information is not uniformly covered in publicly available records. As a result, it has not been possible to obtain information on the Slovenian tourism programs offered by higher education institutions in Slovenia, or, therefore, to analyse the correlation between them and to determine the quality of individual programs.

The second problem stems from the original problem, because without information on the Slovenian tourism education programs being offered, it was not possible to conduct a comparative analysis or substantiate content quality. Praprotnik Gomzijeva (2009) described several skills that are important for the future of the Slovenian tourism industry, and this included the ability to adapt quickly to changes and observations, knowledge in the field of information technologies and capabilities for managing new passenger connections such as low-cost flights. The proposed knowledge has a defined objective and utilisable value. According to the theories of David Airey (2008), such knowledge is referred to as professional skills, and in the history of tourism education development it is an economically focused foundation on which other scientific branches, over several phases, have built up the scientific field of tourism, as we know it today. In reality, we are still far from perfect in terms of the maturity of this scientific branch. While the industry has begun to support itself (Kim, Savage, Howey \& Van Hoof, 2009) to some extent, it has not yet outgrown its so-called rigid economic usefulness and focused basis. Academic knowledge is required, which corresponds to the double-sided character of tourism as a branch (Paris, 2011). The academic knowledge of tourism is neglected (Fidgeon, 2010) and still waiting to reinforce this abstract knowledge, which is crucial for understanding complex phenomena in tourism, to calibrate, balance and complete the field of the science of tourism. In theory, with such a balanced approach, prospective employees could better understand tourism and thus achieve better results, which would raise the value of tourism employees who currently work hard for low pay; lower even than the expectations of tourism students (Zagonari, 2009). But such a balanced system can act in opposition to the interests of stakeholders and employers. As Fidgeon (2010) says, prospective personnel must meet the needs of the tourism economy and not vice versa. Consequently this means that a state, which organises personnel education to meet the needs of its industries, must know its education system and its contents, and control them to suit the 
aforementioned needs. Certainly, different tourist economies seek different personnel, and in the study by Acolla Lewis (2005), stakeholders have shown interest for personnel with managerial competencies, transferable skills, an expanded understanding of tourism and an independent and holistic way of thinking. This brings us to the third dimension in tourism education, which is the dimension of transferable competencies. These are not taught as part of the educational program, but they are gained during the training process (Stergiou, Airey, \& Riley, 2008)(Paris, 2011). They are specific to each individual and are applied to all areas of work. In general, good working practices, conscientiousness, ethical responsibility and specific competencies that help the individual perform their work and, in addition to this, success, they also develop a more mature personality; all of these as side effects of successful learning techniques. The future of tourism education is reserved for those who balance competence between the profession and academia, with the educational process adding key transferable skills (Inui, Wheeler, \& Lankford, 2006). In December 1994, the UK hosted an academic conference for the Association for Tourism in Higher Education (ATHE) identifying seven key bodies of knowledge, which in their opinion, provides for balanced teaching of competencies for future tourism graduates. These are: understanding the scope and nature tourism, the structure of the tourism industry, dimensions of tourism and the problem of measuring the importance and impact of tourism, tourism marketing, tourism planning and development, policy and management (Fidgeon, 2010). These seven bodies of knowledge require competence areas in which the subjects of educational programs are designed, and through the learning process give some competencies that are consistent with one or more competence areas. This is the logical sequence that we selected for the survey, and also the basis for the analysis of Slovenian tourism undergraduate programs.

\section{Form of the slovenian education space}

In the pilot analysis of the programs of study phase, we found certain characteristics, confirmed by the fact that the courses were designed not on the basis of the identified competencies needed by graduates, but on the basis of the human resources available in each higher education institution. As a result, we questioned the constructive approach to the analysis and design of the competencies that are required by Slovenian tourism workers to realize sustainable development objectives in Slovenia. The majority of the largest Slovenian educational institutions are state-owned (public state universities). There are five according to the latest figures; in addition, there are 30 independent institutions of higher education (Ministrstvo za visoko šolstvo, znanost in tehnologijo, 2011). Public institutions are financed from the state 
budget, while the remainder are self-financed with the help of concessions or participation in public tenders (Ministrstvo za izobraževanje, znanost in šport, 2012). The Higher Education Act (Ministrstvo za izobraževanje, znanost in šport, 2012) and the Vocational Education Act (Ministrstvo za izobraževanje, znanost in šport, 2004) also describe a binarily-opposed education, with higher education and higher professional education programs offering a more skills-based orientation; university programs with academic orientation offering less practical experience. The resolution of the National Programme of Higher Education is not only a document describing the functioning of the education system in the Republic of Slovenia, but it is also a document which describes the planned development of the Slovenian education space until 2020. Key to this, is that the document represents the state's effort to guide education, which initially was considered a large limiting factor for tourism programs. In fact, the only limitations are in terms of financing the programs, which is consistent with the current economic climate and state policy. The document defines the oversight of the programs and operation of educational institutions from the point of NAKVIS, which accredits institutions, thus conferring the right to offer programs. Within its authority, NAKVIS defines the adequacy of the study program and, within the Slovenian space, whether there are legitimate requirements for specific graduate profiles (Nacionalna agencija Republike Slovenije za kakovost v visokem šolstvu, 2013). NAKVIS cooperates with the major international agencies for quality control in education, EQAR and ENQA (Ministrstvo za šolstvo in šport, 2011). There are no limits to content of the programs except for quality control, and they themselves say that the need for a particular program is about ensuring a high level of training and research in Slovenian higher education (Nacionalna agencija Republike Slovenije za kakovost v visokem šolstvu, n.d.). The lower limits of the educational programs otherwise comply with the directives of the Bologna system, together with laws providing autonomy in decision-making for higher education and postsecondary institutions (Confederation of EU Rectors' Conferences and the \& Association of European Universities (CRE), 2000). In addition, it should be noted that, according to the Ministry of Education, Science and Sport there is an anomaly in our vocational programs, in contrast to the Bologna Declaration, which completes training to the 1st Bologna level after only two years of education. The Slovenian post-secondary and higher tourism education system complements national vocational qualifications (NPK). Through NPKs, the Slovenian tourism industry can also be effective in adjusting the need for the specific skills and competencies of the labour market. In any event, it is a reflection of the low academic status of tourism and people's attitudes to this academic orientation (Mayaka \& Akama, 2007). It is interesting that from a legal perspective the NPK and Diploma in 
Tourism are by no means equivalent levels of education (Ministrstvo za delo, družino, socialne zadeve in enake možnosti, 2006), but in some cases target the same places of employment. NPKs are also much shorter and their educational programs include competencies for specific employment. While NPKs, on the one hand, cast a bad light on the whole academic field of tourism, we cannot say that they are unnecessary, since they play a key role in employee training or retraining and lifelong learning (Gudeva, Mitrev, Janevik, \& Boev, 2012). This is exemplified by the fact that the majority of NPK educational programs are proposed and created with the help of Slovenian companies that are engaged in tourism and related industries (Ministrstvo za delo, družino, socialne zadeve in enake možnosti, 2010). Of course, in this way, stakeholders participate in the development and calibration of the whole tourism education system. This opinion should then be balanced by academia, thus not being completely dominated by the professional aspects and, above all, this should ensure a country-specific system of education adapted to their needs (Cervera-Taulet \& Ruiz-Molina, 2008). More or less the success of the tourism educational system (or any other industry) requires system integration and communication, which in Slovenia is difficult to measure. The Bologna reforms in the Slovenian higher education system introduce a systematic approach and formalization, which could be beneficial if such reforms are carried out on the basis of previous analysis.

\section{Methodology}

We identified the specifics of Slovenian tourism and conducted a brief overview of the educational programs in accordance with all the information obtained, and, at the same time, using the ideals of a balanced program, we compiled a competency table, which we used to examine the dimensions of Slovenian undergraduate programs. We recorded the name of the educational institution, program title, subject titles, and competence areas, where we could classify individual competencies, offered by individual courses. The areas classified as professional competence areas were: hospitality, organizational skills/management, hospitality/culinary, components of tourism, economics/business and IT knowledge. The academic competence areas correspond to: research skills, foreign languages and social tourism. Transferable skills were recorded in the second segment. In addition, we also added specific competence areas and specific transferable skills. The data was collated from the catalogues of individual educational programs. The study included 12 programs from six higher education institutions. After collating the competency analysis as provided by programs of study, we compared the latter with competence/ requirements defined by the Slovenian tourism industry. In addition, a comparison was 
made for compliance with the seven key bodies of knowledge; we made assumptions as to guidelines for a balanced educational program of tourism. Our hypotheses were, H1: In comparing competence/ areas on Slovenian undergraduate courses in tourism, "Research Skills" will have the lowest score; H2: That Slovenian undergraduate programs on average cover at least $60 \%$ of professional competence requirements and H3: Slovenian undergraduate programs do not follow the guidelines of a balanced program defined in the theoretical part.

\section{The survey results}

The results showed that hypothesis $\mathrm{H} 1$ is false, and that the lowest score across competence areas was hotel management rather than research skills. We also reject hypothesis $\mathrm{H} 2$, because the average of all competencies scored only $57.89 \%$ against the professional competence requirements, which is insufficient to satisfy the condition. Hypothesis H3 was rightly rejected, as analysis of content showed some full and partial matches to the balanced educational program of tourism proposed. It is therefore not possible to say that Slovenian tourism undergraduate programs do not follow these guidelines. More specifically, the comparative work demonstrates that the skills and competence areas partially or fully meet five of the seven key bodies of knowledge. We note, and it is our opinion, that the vast majority of professional competencies meet the needs of the Slovenian tourist area. We also observed the introduction of professional practices in the university program at the Brežice Faculty of Tourism. In general, the coverage lacked competence in the field of logistics and transport in the tourism industry, which, among others, was exposed as an important dimension of Slovenian tourism.

\section{Conclusion}

The research has shown the competence areas that are best represented, and in which programs. Competence/skill areas for hotel management are very weakly represented. The highest number with just two subjects are the Business Systems in Tourism (PST) program at FTŠ Turistica, the Catering and Tourism (CTUR) programs at Maribor VSŠGT and Bled VSŠGT, and the university (UNI) program at EF Ljubljana. Organisational skills and management are highly represented in the PST program at Turistica, with 27 subjects. Accommodation and catering are well represented by the CTUR programs at VSŠGT Maribor and Bled, with as many as 17 subjects providing the competencies in this field. Elements of Tourism is best delivered by the PST program at Turistica and by the UNI program at FT Brežice. A peculiarity and, at the same time, an anomaly, Economics and Entrepreneurship appears as the field of competence with by 
far the largest representation of 39 subjects, on the UNI program at EF Ljubljana. The highest representation in the IT competence area is reflected in the Management of Tourist Destinations (MTD) program at Turistica (10 subjects). The best representations for foreign language programs are found on GTUR from VSŠGT Maribor and Bled (6 subjects). The Tourism (TUR) program from Celje FKPV faculty (19 subjects) stands out in representation of the Social Studies in Tourism competence. Transferable skills in "other" areas of competence are best represented in UNI program at Turistica with 22 subjects. It is important to mention that VSŠGT Bled and Maribor VSŠGT used identical subject catalogues as they are part of a consortium of vocational colleges for Hospitality and Tourism. The average number of represented competence areas has shown that undergraduate programs in Slovenia in tourism largely represent organizational knowledge management, followed immediately by transferable skills, and then economics and entrepreneurship. This data is also apparent in the following table, along with other information covered.

The study has limitations arising from the limited access to relevant information. The results show that the competencies in study programs are relatively well covered, which highlights the tourism economy on the one hand and the theory of the balance of competencies of workers in the tourism sector, on the other hand. At the same time, the survey also revealed competence areas that are not fulfilled by tourism study programs in Slovenia. To optimize Slovenian tourism education, we believe that there should greater control of content in education, ensuring better graduate employability, which does not occur without the explicit involvement of the state. NAKVIS already does this, but even with NAKVIS control, there remains major growth in tourism education because of the exclusion of private educational institutions from the national higher education program. We believe that even the Bled and Maribor vocational colleges for Catering and Tourism need to diversify their programs, and the whole of the Slovenian higher educational system, should last one year more as determined by the Bologna declaration.

We believe that this study also needs some improvements. Collation of undergraduate programs and their content only from subject catalogues may be highly misleading, because the realities of university programs vary considerably from written documentation. Sometimes the documentation itself does not provide sufficient detail to draw completely reliable data from them. To determine individual competence areas would require a separate study to define the precise ranges, and the competencies that correspond to these areas. The present study has opened up questions, which will require further research on the quality of competencies in the field of Slovenian tourism study programs. 


\section{References:}

Cervera-Taulet, A., \& Ruiz-Molina, M.-E. (2008). Tourism education: a strategic analysis model. Journal of Hospitality, Leisure, Sport and Tourism Education, 7(2), 59-70.

Confederation of EU Rectors' Conferences and the, \& Association of European Universities (CRE). (2000, February 29). The Bologna Declaration on the European space for higher education: an explanation. Evropska Komisija. Retrieved from

http://ec.europa.eu/education/policies/educ/bologna/bologna.pdf

Fidgeon, P. R. (2010). Tourism education and curriculum design: A time for consolidation and review? Tourism Management, 31(6), 699-723.

Gudeva, L. K., Mitrev, S., Janevik, E. I., \& Boev, B. (2012). Implementation of national qualification framework for higher education in Republic of Macedonia. Procedia-Social and Behavioral Sciences, 46, 2556-2560.

Inui, Y., Wheeler, D., \& Lankford, S. (2006). Rethinking tourism education: What should schools teach. Journal of Hospitality, Leisure, Sport and Tourism Education, 5(2), 25-35.

Mayaka, M., \& Akama, J. S. (2007). Systems approach to tourism training and education: The Kenyan case study. Tourism Management, 28(1), 298306.

Ministrstvo za delo, družino, socialne zadeve in enake možnosti. (2006, November 17). Zakon o nacionalnih poklicnih kvalifikacijah. Retrieved from http://www.uradni-list.si/1/objava.jsp?urlid=20071\&stevilka=4

Ministrstvo za delo, družino, socialne zadeve in enake možnosti. (2010, January 1). Nacionalna poklicna kvalifikacija. Retrieved April 12, 2013, from http://www.npk.si/index.php?subpageid=5\&katid=32\&searchq= Ministrstvo za izobraževanje, znanost in šport. (2004, July 23). Zakon o višjem strokovnem izobraževanju. Retrieved from http://www.uradnilist.si/1/objava.jsp?urlid=200486\&stevilka=3840

Ministrstvo za izobraževanje, znanost in šport. (2012, April 19). Zakon o visokem šolstvu. Retrieved from http://www.uradnilist.si/1/objava.jsp?urlid=201232\&stevilka=1406

Ministrstvo za šolstvo in šport. (2011, March 31). Bela knjiga o vzgoji in izobraževanju v Republiki Sloveniji. Retrieved from http://www.belaknjiga2011.si/pdf/bela_knjiga_2011.pdf

Ministrstvo za visoko šolstvo, znanost in tehnologijo. (2011, Maj). Resolucija o nacionalnem programu visokega šolstva. Retrieved from http://www.uradni-list.si/1/content?id=103885

Nacionalna agencija Republike Slovenije za kakovost v visokem šolstvu. (2013, April 5). Brošura nakvis. Retrieved from http://test.nakvis.si/slSI/Content/GetFile/235 
Nacionalna agencija Republike Slovenije za kakovost $\mathrm{v}$ visokem šolstvu. (n.d.). Nakvis.si. Retrieved from http://test.nakvis.si/sl-SI/News/Details/120 Paris, C. M. (2011). Social constructivism and tourism education. Journal of Hospitality, Leisure, Sports and Tourism Education, 10. Retrieved from http://www.jisctechdis.ac.uk/assets/hlst/documents/johlste/vol10no2/PP3385 Paris103to108.pdf

Stergiou, D., Airey, D., \& Riley, M. (2008). Making sense of tourism teaching. Annals of Tourism Research, 35(3), 631-649. 